\title{
$\begin{array}{lllllllll}\mathrm{I} & \mathrm{N} & \mathrm{S} & \mathrm{T} & \mathrm{I} & \mathrm{T} & \mathrm{U} & \mathrm{T} & \mathrm{E}\end{array}$
}

\section{The Effects of State EITC Expansion on Children's Health}

$\mathrm{T}$ The Earned Income Tax Credit (EITC) is currently the nation's largest federal income support program, with twenty-seven million working households receiving credits in the 2009 tax year. ${ }^{1}$ In addition, during the past twenty years, twenty-four states have implemented their own EITCs. One of the primary goals of the credit is to increase the family incomes of low-wage workers and lift children in these families out of poverty. In this way, the EITC also has the potential to improve child health outcomes. Higher family income may improve child health by making medical care and other health-improving behaviors (such as eating healthier food) more affordable. On the other hand, maternal employment, which the EITC encourages (particularly for single mothers), may reduce the amount of time that a mother spends with her child. Such reduced time may have adverse effects on child health. ${ }^{2}$ Alternately, employment may boost self-confidence and increase the skills of some mothers, leading to improvements in child health. Employment is also likely to expand the set of resources that parents can use to improve child health, including income and health insurance coverage.

This brief examines the impact of state-level adoption of EITCs on a set of health-related outcomes for children, including: (1) health insurance coverage, (2) use of preventive medical and dental care, and (3) health status measures including maternal reports of child health and body mass index (BMI). It also considers the possibility that the effect of the EITC on these outcomes may vary depending on where a child lives; families in urban and rural communities have different access to medical care and other resources that promote good health.

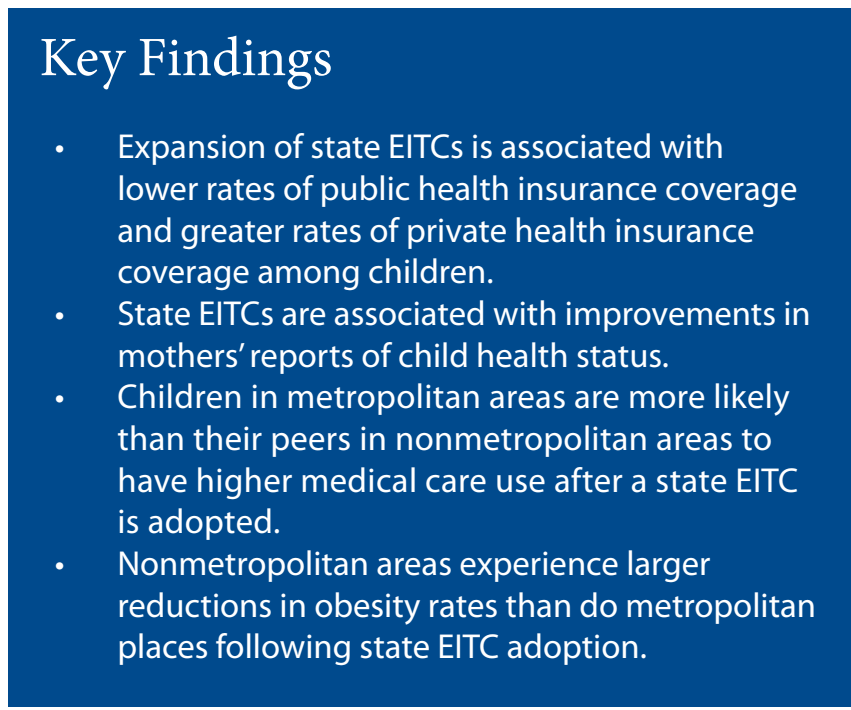

\section{The EITC: Raising Income and Promoting Work}

The federal EITC was established in 1975. It was set at a modest level intended to offset the regressivity of the (FICA) payroll tax. ${ }^{3}$ Since that time, the credit has been expanded many times, with the largest federal expansions occurring between 1994 and 1996. A higher credit level for families with two or more children was added in 1994, and an even higher credit level for families with three or more children was added in 2009. As Figure 1 shows, the maximum federal credit available in 2010 ranged from $\$ 3,050$ for families with one child to $\$ 5,666$ for families with three or more children. ${ }^{4}$ The maximum income at which parents were eligible for the EITC in 2010 ranged from $\$ 35,535$ (for households with one child) to $\$ 43,352$ (for households with three or more children). 
Figure 1. Federal EITC FOR 2010

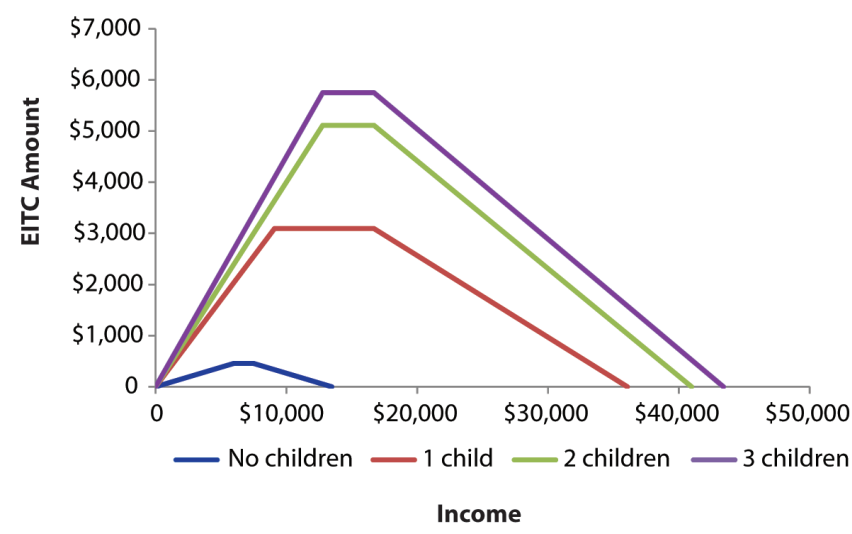

During the 1980s, states began to add their own supplements, usually set as fixed percentages of the federal EITC, and ranging from 5 percent to more than 50 percent of the federal credit. By 2009, twenty-four states had their own EITC. Figure 2 shows the growth of state EITCs over the period 1992-2011.

\section{Figure 2. States With EITC}

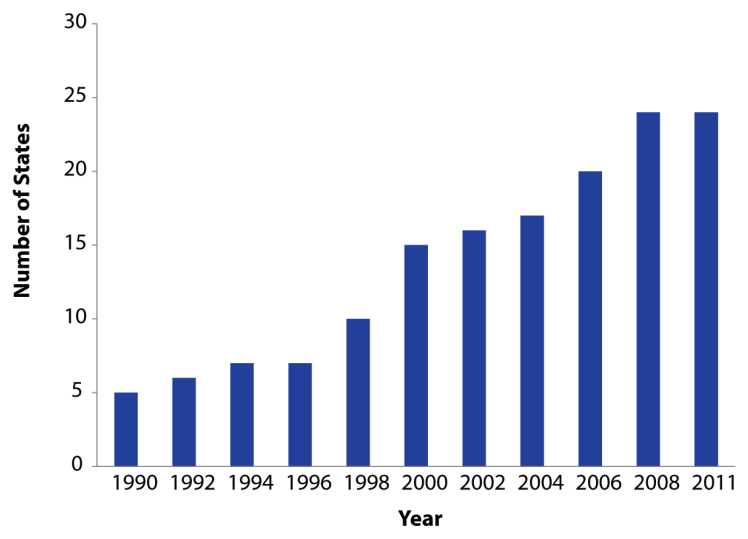

The EITC is available only to tax filers with earned income. During the phase-in range, the credit increases with each dollar earned; the initial value of the credit is a fixed percentage of earnings (for example, 45 percent of the first $\$ 12,600$ in annual earnings in 2010 for a family with three or more children). The credit then plateaus at set earnings thresholds and eventually phases out as income increases further. ${ }^{5}$ The phased-in structure of the credit provides a strong incentive for parents to start working. Numerous research studies have suggested that the EITC has increased family income, reduced child poverty, ${ }^{6}$ and promoted employment, particularly for single mothers who have low levels of education. ${ }^{7}$

\section{Children in States that Adopt EITCS Have More Private Health Insurance Coverage and Better Health Status}

One way to test whether the EITC results in better child health is to compare health outcomes before and after a state adopts its own EITC. ${ }^{8}$ This brief examines changes in health-related outcomes for children in the fourteen states that adopted EITCs between 1990 and 2006. ${ }^{9}$ As Table 1 indicates, the fourteen states that adopted EITCs between 1990 and 2006 show considerable changes in health insurance coverage over this time period. The proportion of children covered by private health insurance increased by 8.4 percent, while participation in public health insurance programs like Medicaid and State Children's Health Insurance Programs (SCHIPs) fell by 13.9 percent. As a result, the total fraction of children who were insured did not change significantly. This shift from public to private coverage may be the result of more parents working or more parents working full time in jobs that provide health benefits.

TABLE 1. DifFERENCES IN OUTCOMES BEFORE AND AFTER EITC IMPLEMENTATION

\begin{tabular}{|c|c|c|c|c|c|}
\hline & $\begin{array}{l}\text { Before } \\
\text { EITC }\end{array}$ & $\begin{array}{l}\text { After } \\
\text { EITC }\end{array}$ & $\begin{array}{c}\text { Percent } \\
\text { Difference }\end{array}$ & $\begin{array}{c}\text { Statistically } \\
\text { Significant } \\
\text { Difference } \\
(\mathrm{P}<.05)\end{array}$ & $\begin{array}{l}\text { EITC Effect } \\
\text { Significant in } \\
\text { Full Analysis }\end{array}$ \\
\hline Private Health Insurance & $68.2 \%$ & $74.2 \%$ & $8.4 \%$ & Yes & Yes $^{1}$ \\
\hline Public Health Insurance & $23.1 \%$ & $20.1 \%$ & $-13.9 \%$ & Yes & Yes $^{1}$ \\
\hline Annual Doctor Visit & $70.3 \%$ & $70.4 \%$ & $0.1 \%$ & & \\
\hline Annual Dental Visit & $56.5 \%$ & $69.8 \%$ & $21.1 \%$ & Yes & \\
\hline Excellent Health & $68.1 \%$ & $69.8 \%$ & $2.5 \%$ & & Yes $^{2}$ \\
\hline Overweight & $28.7 \%$ & $30.1 \%$ & $4.8 \%$ & & \\
\hline Obese & $16.9 \%$ & $17.1 \%$ & $1.2 \%$ & & \\
\hline Underweight & $11.3 \%$ & $7.0 \%$ & $-47.0 \%$ & Yes & \\
\hline
\end{tabular}

0 - Baughman \& Duchovny (see endnote 11)

1 - for children ages 6-14

2 - for children ages 11-14

However, these differences may simply reflect changes in the personal and family characteristics of children over time, changes in state-level economic and health conditions, or the fact that the analysis observed the same child multiple times in multiple years in the data. ${ }^{10}$ In addition, two other public programs that could conceivably have affected child healthMedicaid and AFDC/TANF - were also changing during this time period. After statistically adjusting for all of these factors, the changes we observe in health insurance coverage patterns remain sizeable and significant. ${ }^{11}$

The utilization rates in Table 1 suggest that implementation of a state EITC is also associated with higher levels of dental care use for children. In states adopting an EITC, children were 24 percent more likely to have visited a dentist in the year after adoption. This may be the result of higher family incomes that 
make dental care affordable, or it may be that private health insurance provides better access to dentists. ${ }^{12}$ The effect could be a meaningful one because low-income children are almost twice as likely as children from high-income families to have unmet needs for dental care. ${ }^{13}$ One study estimates that by the teen years (ages 13-17), dental health problems are estimated to result in more than 1.5 days of school missed per child per year. ${ }^{14}$ However, after statistically adjusting for the factors discussed above, the increase in dental care visits that is observed in Table 1 largely disappears.

The health status of children also appears to improve after the implementation of a state EITC. The percentage of children whose mothers report them to be in excellent health rises by 2.5 percent. ${ }^{15}$ Although this difference is not statistically significant, after controlling for a full set of factors that could contribute to health, the EITC is associated with a significant increase in excellent health status for children ages 11 to 14 . In addition, EITC adoption seems to be associated with an overall shift toward higher body weight for height, or BMI. In states that implement EITCs, the proportion of children who are underweight falls by a dramatic 47 percent; however, this difference largely disappears and is not statistically significant after the full set of statistical controls is added.

There may be multiple factors contributing to these health status changes. While higher family income seems to be the most likely cause of health improvements, private health insurance coverage may also contribute by providing better access to higher-quality medical care..$^{16}$ In addition, increased employment among mothers may contribute to better health for some older children. One recent study finds that maternal employment is associated with improved cognitive outcomes for socioeconomically disadvantaged 10and 11-year-old boys. ${ }^{17} \mathrm{~A}$ similar effect may exist for health outcomes. On the other hand, the increase in the proportion of overweight children may be linked to increased affordability of convenience foods-working mothers having less time to prepare healthy meals-or a combination of the two.

\section{Children in Less Urban Areas Are Affected Differently by EITC Adoption}

The health effects of adopting a state EITC may affect children differently depending on where they live. Parents in less urban areas may have access to fewer health insurance options and fewer medical providers for their children. In addition, the underlying health status of children in more urban areas may be different before an EITC is adopted. To examine how geography affects the impact of state EITC on child health, this analysis separates children by those who live in a metropolitan county and those who live in a nonmetropolitan county. ${ }^{18}$ The results presented in Table 2 show several significant geographical differences.
TABLE 2. DIFFERENCES IN PRE- VERSUS POST-EITC CHANGES, BY AREA OF RESIDENCE*

\begin{tabular}{|c|c|c|c|}
\hline & $\begin{array}{c}\text { Metropolitan } \\
\text { Areas }\end{array}$ & $\begin{array}{c}\text { Non } \\
\text { Metropolitan } \\
\text { Areas }\end{array}$ & $\begin{array}{c}\text { Statistically } \\
\text { Significant } \\
\text { Difference } \\
(\mathrm{P}<.05)\end{array}$ \\
\hline Private Health Insurance & $8.0 \%$ & $16.7 \%$ & \\
\hline Public Health Insurance & $-13.5 \%$ & $-17.6 \%$ & \\
\hline Annual Doctor Visit & $2.1 \%$ & $-12.0 \%$ & Yes \\
\hline Annual Dental Visit & $23.1 \%$ & $6.3 \%$ & Yes \\
\hline Excellent Health & $2.2 \%$ & $3.4 \%$ & \\
\hline Overweight & $10.9 \%$ & $-42.9 \%$ & \\
\hline Obese & $7.4 \%$ & $-49.6 \%$ & Yes \\
\hline Underweight & $-47.0 \%$ & $-55.1 \%$ & \\
\hline
\end{tabular}

* The following pre-versus post-changes are statistically significant $(p<0.05)$ for Metropolitan Areas: Private Health Insurance, Public Health Insurance, Annual Dental Visit, Overweight, and Underweight. The significant pre- versus post-changes for Nonmetropolitan Areas are: Private Health Insurance, Overweight, Obese.

One difference is that children in metropolitan areas are much more likely than their peers in nonmetropolitan areas to have greater health care use after an EITC is implemented. There is also a very large difference in changes in annual dental visits over time for children in nonmetropolitan $(6.3$ percent) versus metropolitan (23.1 percent) areas. This suggests that providing financial support, whether in the form of income or health insurance, will not necessarily by itself result in higher use of routine preventive care. Access to doctors, dentists, and other medical care providers who accept a given form of insurance (or self-paying patients) may also be important. Given the relatively fewer health resources available in rural communities, health insurance coverage is only one of many potential barriers to health care access. Others include transportation, distance, and provider availability. It is also possible that the income and employment effects of the EITC differ by geographic region. Specifically, the data used in this analysis suggest that the post-EITC increase in maternal employment is much stronger in metropolitan areas.

In terms of health status outcomes, the only significant differences by area of residence in response to the implementation of state EITCs are for obesity rates. Although the overall effect is not statistically different from zero, it is made up of significantly different effects in metropolitan and nonmetropolitan areas. In this case, children in nonmetropolitan areas experience much larger reductions in obesity than do their peers in metropolitan areas. It is difficult to say what might be driving this pattern, but it is possible that higher family income has different effects on food consumption patterns depending on the relative availability of different types of food (that is, access to grocery stores with produce sections versus fast-food restaurants or convenience stores) in different areas. 


\section{Policy Implications}

Based on comparisons of children before and after a statelevel EITC is adopted, an earned income tax credit appears to be associated with an aggregate shift away from public health insurance coverage through Medicaid and SCHIP and toward private health insurance coverage. It is not entirely clear whether this is, in and of itself, a positive outcome for children. After adjusting for differences in the characteristics of children in states with and without an EITC, the credit is associated with very little change in the total number of children who are insured. However, the quality of public and private health insurance plans may differ. On one hand, most state public insurance programs have a very high level of coverage, with services like eye care and dental care covered more frequently than they are in private plans, and relatively low cost sharing. The broad extent of coverage on paper may be of limited value in practice, though, if children on public plans live in geographic areas with few doctors who participate in the plan. ${ }^{19}$ Further, the medical care providers who only participate in private health insurance plans may offer higher quality medical care.

Implementation of a state EITC also appears to be associated with a significant improvement in a child's health status as reported by the child's mother. This is not only a good outcome for children and their families in the near term, but it is also likely to produce better lifetime outcomes. Considerable evidence suggests that better health in childhood translates to both better health outcomes later in life and better educational and employment outcomes. ${ }^{20}$

\section{Data}

The primary data source for this analysis is the National Longitudinal Survey of Youth 1979 (NLSY79) Cohort, which is attached to the Child and Young Adult (CYA) supplement. The NLSY79 is a multi-year survey of a nationally representative sample of 12,686 individuals aged 14-21 in 1979. The first interviews occurred in 1979, and respondents were interviewed annually until 1994 and then every two years thereafter. Information about all children born to these original sample members has been collected in the CYA file from birth; health-related variables for these children were first collected in 1992. The sample used in this analysis includes data from 1992 to 2006 and includes only children aged 14 and under whose mothers have less than a college education. Given that the EITC is an income-targeted program, very few women with college degrees qualify to claim the credit. Because children are born into and age out of the sample, the sample size varies by year, ranging from 5,015 children in 1992 to 1,360 in 2006. Because of the longitudinal design of the survey and because I was able to use only data from 1992 onward, the children in my sample over-represent births to older mothers. Thus, these children have slightly higher family incomes and health insurance coverage rates than the national average. Unless otherwise noted, differences discussed in this brief are statistically significant $(\mathrm{p}<0.05)$. 
ENDNOTES

1. Center on Budget and Policy Priorities, "Policy Basics: The Earned Income Tax Credit” (Washington, DC: Center on Budget and Policy Priorities, 2011). Available at http:// www.cbpp.org/cms/index.cfm?fa=view\&id=2505. Accessed September 12, 2011.

2. See Suzanne M. Bianchi, "Maternal Employment and Time With Children: Dramatic Change or Surprising Continuity?" Demography, vol. 37, no. 4 (2000): 401-414. The author argues that although evidence suggests that working mothers spend fewer hours with children compared with non-working mothers, the gap in "quality" time spent with children may be much smaller.

3. Saul D. Hoffman and Laurence S. Seidman, "The Earned Income Tax Credit: Antipoverty Effectiveness and Labor Market Effects" (Kalamazoo, MI: W.E. Upjohn Institute for Employment Research, 1990).

4. There is a much smaller credit, $\$ 457$ in 2010 (the maximum credit), for income tax filers who do not have children.

5. Center on Budget and Policy Priorities, "Policy Basics: The Earned Income Tax Credit” (Washington, DC: Center on Budget and Policy Priorities, 2011). Available at http:// www.cbpp.org/cms/index.cfm?fa=view\&id=2505. Accessed September 12, 2011.

6. See, for example, Molly Dahl, Thomas DeLeire, and Jonathan Schwabish, "Stepping Stone or Dead End? The Effect of the EITC on Earnings Growth," National Tax Journal, vol. 62, no. 2 (2009): 329-346; and D. Neumark and W. Wascher, "Using the EITC to Help Poor Families: New Evidence and a Comparison to the Minimum Wage," National Tax Journal, vol. 54, no. 2 (2001): 281-318.

7. See, for example, Nada Eissa and Jeffrey B. Liebman, "Labor Supply Response to the Earned Income Tax Credit," Quarterly Journal of Economics, vol. 111, no. 2 (1996): 605-637; Bruce D. Meyer and Dan T. Rosenbaum, "Making Single Mothers Work: Recent Tax and Welfare Policy and its Effects," National Tax Journal, vol. 53, no. 4 (2000): 10271062; and Jeffrey Grogger, "The Effects of Time Limits, the EITC and Other Policy Changes on Welfare Use, Work, and Income among Female-headed Families," Review of Economics and Statistics, vol. 85, no. 2 (2003): 394-408.

8. Note that the EITC is associated with both higher income and higher employment levels for single mothers. While higher income should promote better health, maternal employment may have a negative impact on health for some children, especially younger children. This issue is discussed in depth in Reagan Baughman and Noelia Duchovny, "The EITC and Production of Child Health: Insurance Coverage, Utilization, and Health Status," Working paper (Durham, NH: University of New Hampshire, 2012).
9. The states that adopted EITCs between 1990 and 2006 are as follows: Colorado (1999), Delaware (2006), Illinois (2000), Indiana (2003), Kansas (1998), Maine (2000), Massachusetts (1997), Minnesota (1991), Nebraska (2006), New Jersey (2000), New York (1994), Oklahoma (2002), Oregon (1997), and Virginia (2006).

10. These issues, as well as more technical data issues, are discussed in Baughman and Duchovny, "The EITC and Production of Child Health."

11. See Baughman and Duchovny ("The EITC and Production of Child Health") for these results.

12. See Leighton $\mathrm{Ku}$, "Medical and Dental Care Utilization and Expenditures under Medicaid and Private Health Insurance," Medical Care Research and Review, vol. 66, no. 4 (2009): 456-471. This study shows that privately insured children have significantly more dental visits than children who have Medicaid, although this difference is not statistically significant after controlling for differences between the two groups in health status and other characteristics.

13. See Genevieve M. Kenney, Grace Ko, and Barbara Ormond, "Gaps in Prevention and Treatment: Dental Care for Low Income Children," New Federalism: National Survey of America's Families: series B, no. B-15 (Washington, DC: The Urban Institute, 2000).

14. See Helen C. Gift, Susan T. Reisine, and Dina C. Larach, "The Social Impact of Dental Problems and Visits", American Journal of Public Health, vol. 82, no. 12 (1992): 1663-1668.

15. The alternatives are fair, poor, or good health.

16. There is little in the way of direct evidence on this question. Ku ("Medical and Dental Care Utilization") shows that per capita medical expenditures in many categories are higher for privately insured children compared with children covered by Medicaid. This may indicate a higher quality of care, but it could also be explained by differences in provider reimbursement rates or other factors.

17. See Christopher J. Ruhm, "Maternal Employment and Adolescent Development," Labour Economics, vol. 15, no. 5 (2008): 958-983. The results of this study suggest that 10- to 11-year-old boys from disadvantaged socioeconomic backgrounds show small improvements in cognitive outcomes when their mothers are employed. However, other studies suggest modest adverse health effects. See Lisa A. Gennetian et al., "Maternal Employment and the Health of Low-Income Young Children," Journal of Health Economics, vol. 29, no. 3 (2010): 353-363. 
18. Counties were coded using 2003 Rural-Urban Continuum Codes provided by the U.S. Department of Agriculture, available at www.ers.usda.gov/Briefing/Rurality/RuralUrbCon/. This is not a perfect measure of urban versus rural residence status, since some children in the nonmetropolitan counties may live in relatively densely populated suburban areas. However, there were too few children in this survey who lived in more rural counties to permit a separate analysis.

19. See Jack M. Colwill and James M. Cultice, "The Future Supply of Family Physicians: Implications for Rural America," Health Affairs, vol. 22, no. 1 (2003): 190-197.

20. See, for example, Anne Case, Angela Fertig, and Christina Paxson, "The Lasting Impact of Childhood Health and Circumstance," Journal of Health Economics, vol. 24, no. 2 (2006): 365-389; Sanders Korenman and Jane E. Miller, "Effects of Long-Term Poverty on Physical Health of Children in the National Longitudinal Survey of Youth," Consequences of Growing up Poor, edited by Greg J. Duncan and Jeanne Brooks-Gunn (New York: Russell Sage, 1997), pp. 70-99; and James P. Smith, “The Impact of Childhood Health on Adult Labor Market Outcomes," Review of Economics and Statistics, vol. 91, no. 3 (2009): 478-489.

\section{A B OUT THE AUTHOR}

Reagan Baughman is an associate professor of economics at the University of New Hampshire (reagan.baughman@unh.edu).

\section{A C K N O W LED GE M E N T S}

The author would like to thank the following people for their helpful comments and suggestions: Jon Shure and Erica Williams at the Center on Budget and Policy Priorities; Deborah Stein, Vice-President for Policy, The Hatcher Group, which manages www.TaxCreditsForWorkingFamilies.org; Barbara Ray at Hiredpen; and Curt Grimm, Laurel Lloyd, Bruce Mallory, Beth Mattingly, and Amy Sterndale at the Carsey Institute.

\section{ANIVERSITY Of NEW HAMPSHIRE}

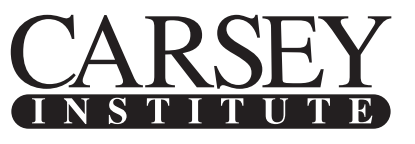

Building knowledge for families and communities

The Carsey Institute conducts policy research on vulnerable children, youth, and families and on sustainable community development. We give policy makers and practitioners timely, independent resources to effect change in their communities.

This work was supported by the Annie E. Casey Foundation, the W. K. Kellogg Foundation, and an anonymous donor.

Huddleston Hall

73 Main Street

Durham, NH 03824

(603) $862-2821$

www.carseyinstitute.unh.edu 